\title{
REVIEW
}

\section{Disease threats to farmed green-lipped mussels Perna canaliculus in New Zealand: review of challenges in risk assessment and pathway analysis}

\author{
A. Castinel ${ }^{1,4}$, S. C. Webb ${ }^{1, *}$, J. B. Jones ${ }^{2}$, E. J. Peeler ${ }^{3}$, B. M. Forrest ${ }^{1}$ \\ ${ }^{1}$ Cawthron Institute, Nelson 7010, New Zealand \\ ${ }^{2}$ Murdoch University, Murdoch, Western Australia 6150, Australia \\ ${ }^{3}$ Centre for Aquaculture Fisheries and the Environment, Weymouth DT4 8UB, UK \\ ${ }^{4}$ Present address: PO Box 5142, Nelson 7010, New Zealand
}

\begin{abstract}
The endemic green-lipped mussel (GLM) Perna canaliculus is a key cultural and economic species for New Zealand. Unlike other cultured shellfish species, GLMs have experienced relatively few disease issues. The apparent absence of diseases in both wild and farmed GLM populations does not preclude risks from environmental changes or from the introduction of overseas mussel pathogens and parasites. Potential for disease exchange between the GLM and other mytilid species present in New Zealand has yet to be elucidated. After reviewing and discussing relevant scientific literature, we present an initial assessment of GLM vulnerability to disease threats and the potential risk pathways for mussel pathogens and parasites into New Zealand and highlight a number of challenges. These include knowledge gaps relevant to GLM susceptibility to exotic pathogens and parasites, risk pathways into New Zealand and biosecurity risk associated with domestic pathways. Considerations and findings could potentially apply to other farmed aquatic species with limited distribution range and/or low disease exposure.
\end{abstract}

KEY WORDS: Mussel $\cdot$ Disease $\cdot$ Shellfish $\cdot$ Risk pathways $\cdot$ Risk management $\cdot$ Biofouling

\section{INTRODUCTION}

Aquaculture is a rapidly growing industry worldwide, with production expected to surpass the wild fishery catch by 2025 (FAO 2015). As aquaculture has intensified, diversified and expanded into new geographic areas, diseases have become an increasingly important constraint on production. Transboundary and emerging diseases are considered to be major limiting factors for continued expansion of global aquaculture production and trade (Hedrick 1996, Subasinghe 2005, Whittington \& Chong 2007, Oidtmann et al. 2011). Losses due to disease have been es-

${ }^{*}$ Corresponding author: steve.webb@cawthron.org.nz timated to be greater than US\$3 billion per annum in Asia alone (Vallat 2017). In marine shellfish (molluscan) aquaculture, pathogens and parasites can result in serious financial, social and environmental impacts, whose nature and magnitude vary widely between locations and species. For example, an Ostreid herpesvirus type 1 (OsHV-1) microvar caused mass mortalities of spat and adult Pacific oysters Crassostrea gigas in both hemispheres (Renault et al. 2000, Segarra et al. 2010, Peeler et al. 2012, Bingham et al. 2013, Paul-Pont et al. 2013). The parasite Marteilia refringens (sensu lato, infecting oysters and mussels) is known to cause serious mortality outbreaks in cul-

() The authors 2019. Open Access under Creative Commons by Attribution Licence. Use, distribution and reproduction are unrestricted. Authors and original publication must be credited. 
tured European flat oysters Ostrea edulis, but its impact in farmed mussels Mytilus galloprovincialis is reportedly limited to condition loss and moderate mortality (Villalba et al. 1993, Pérez Camacho et al. 1997).

The noticeable increase in the occurrence of aquatic diseases in recent years highlights the need to better understand the health of both aquaculture and wild populations of marine shellfish as well as the contributing factors (Harvell et al. 1999, Murray \& Peeler 2005, Peeler et al. 2011). Opportunistic pathogens, such as Vibrio spp., have been implicated in mussel mortality events, often taking advantage of variations in water temperature or salinity weakening the hosts (Romero et al. 2014). Direct impacts of diseases, such as mortality, can be monitored and quantified, whereas indirect effects can be of equal or greater importance but are more difficult to measure. Effects include decreased availability of wild spat, lower end-product value, difficulties accessing markets, costs of disease control to both government (e.g. eradication and laboratory testing for surveillance) and industry (e.g. restriction on movements of live shellfish) and indirect impacts on the community and local economy (Israngkura \& Sae-Hae 2002, Evans 2006).

In contrast with other cultured shellfish around the world, New Zealand's endemic green-lipped mussels (GLMs) Perna canaliculus (farmed under the trademark Greenshell ${ }^{\mathrm{TM}}$ mussels) have experienced relatively few disease issues. GLMs are, economically, the most important aquaculture species in New Zealand, where production is around $94000 \mathrm{t}$ annually (which represents ca. NZ\$300 million of annual sales), and several thousand hectares of water space across 6 temperate coastal or offshore growing regions are occupied (Fig. 1). Beyond its marketable value, the green-lipped mussel, or kūtai, is an iconic species protected by New Zealand's indigenous Māori through their kaitiakitanga, or guardianship of the natural environment. Various endemic pathogens and parasites have been reported for this species, but with the exception of the condition described as digestive epithelial virosis (DEV; Jones et al. 1996), there is no evidence of any major impact on cultured or wild mussel populations in New Zealand (Webb 2013).

The reason for the absence of significant health issues in the GLM is unclear. The disease vulnerability of Perna species is poorly understood compared to other mytilid species. Perna as a genus is confined to the South Atlantic and Indo-Pacific regions and has not been farmed outside of its natural geographic range. As such, opportunities for intensive aquaculture, exposure to new disease agents and subsequent

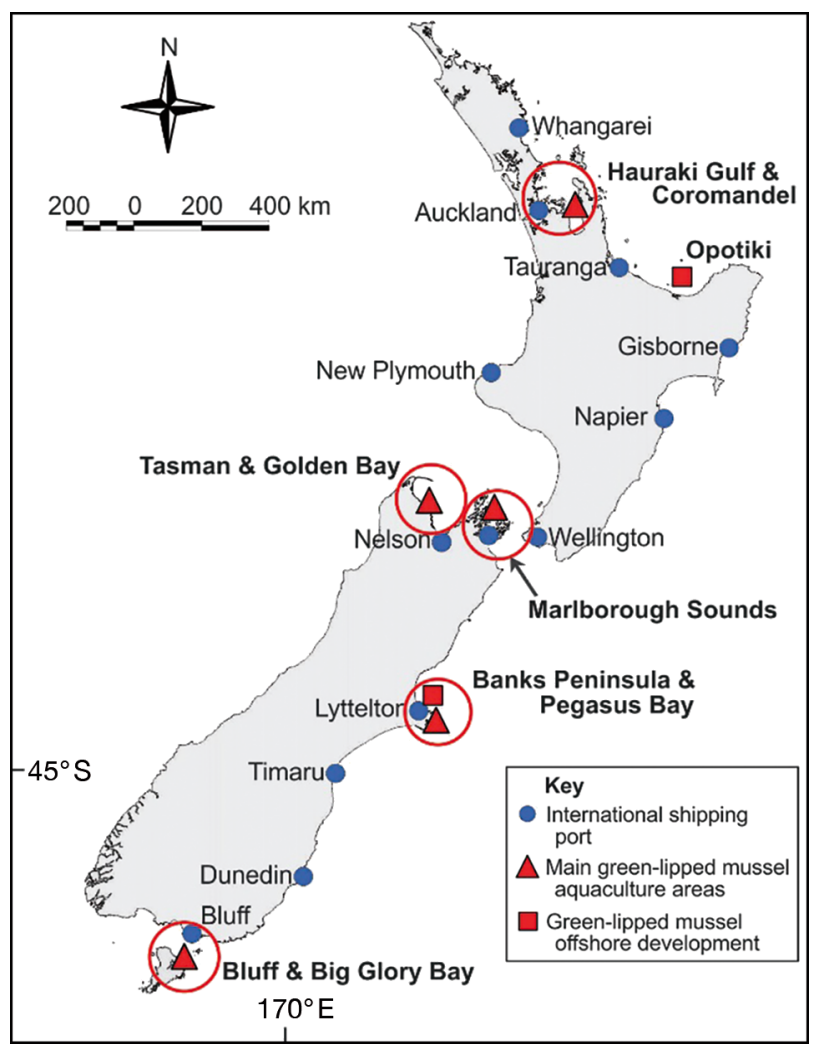

Fig. 1. Main locations of green-lipped mussel aquaculture areas in New Zealand, illustrating their proximity to international shipping ports (circles)

clinical expression have been relatively limited. The apparent healthy status of the GLM population could reflect some inherent resilience of the species or a lack of exposure to exotic pathogens due to New Zealand's geographic isolation. However, this apparent absence of diseases in GLMs needs to be placed within context: first, there is currently no legal requirement for on-farm surveillance, and second, there are no industry-wide standards on acceptable levels of mortality that trigger official reporting and subsequent animal health investigation.

Assessment of potential disease threats to the GLM, and associated uncertainties, is a first step towards identifying the need for, and scope of, appropriate management interventions. As such, this paper reviews the vulnerability of the GLM to disease threats and provides an overview of potential risk pathways for mussel pathogens and parasites into New Zealand. The approach follows guidelines for risk analysis set out by the World Organisation for Animal Health (OIE 2017). Hazard identification takes into account existing records of disease agents and pathological conditions in New Zealand as well as potential exotic agents. Pathways for the introduc- 
tion of pathogens and parasites from outside New Zealand (release assessment) and their spread within the country (part of the consequence assessment) are considered separately. Risk mitigation is discussed in relation to present and potential border controls and domestic risk pathway management. We also identify some of the broader challenges for risk assessment and management, which may apply to the aquaculture of other species with limited global distribution and/or currently limited disease exposure.

\section{ACTUAL OR POTENTIAL DISEASE THREATS FOR GREEN-LIPPED MUSSELS}

\subsection{Existing records of pathogens, parasites and pathological conditions}

The known pathogens, parasites and pathological conditions of GLM and other cultured or wild shellfish species in New Zealand have been reviewed (Webb 2013, Georgiades et al. 2016). Findings are largely based on sporadic screening of commercial or wild stocks (e.g. in response to unexplained mortality) and local ad hoc surveillance. As there has been no systematic or comprehensive national surveillance programme of shellfish diseases to date, existing knowledge is unlikely to provide a complete picture (Castinel et al. 2014). Webb et al. (2019) recently published a consolidation of histological findings from more than 3200 mussel specimens gathered from key production areas around New Zealand between 2007 and 2016. The authors turned the opportunistically collected data into valuable baseline information on pathogens, parasites and conditions of the GLM and Mytilus galloprovincialis (Table 1a,b). The latter mussel species is not commercially farmed in New Zealand, but it is a significant component of the biofouling assemblage on GLM farms (Forrest \& Atalah 2017) and has the potential to play a role in the exchange of pathogens and parasites with GLMs.

GLMs harbour a range of enzootic disease agents as well as parasites such as rickettsiae and apicomplexan parasite X (Hine 2002, Webb 2013). With the exception of DEV being associated with significant spat mortality in the early 1990s (Jones et al. 1996), none of these organisms or conditions are known to have a significant impact on the health of farmed GLMs, wild conspecifics or other shellfish in New Zealand (Castinel et al. 2014). Even for DEV, the actual impact on mussels and other bivalve species, its prevalence in farmed GLMs and potential costs to the aquaculture industry have not been comprehensively evaluated. Further, in spite of histopathologic, transmission electron microscopy and molecular evidence suggesting a viral infection (Jones et al. 1996, Webb 2013), the aetiology of DEV remains obscure.

\subsection{Challenges for hazard identification of potential threats}

Determining, in a systematic way, the future disease threats to GLM aquaculture is a significant challenge. As the GLM is the only Perna species in New Zealand and occurs nowhere else in the world, its susceptibility to new pathogens and parasites is unknown. Furthermore, only 2 other species in the Perna genus are known to exist globally: $P$. viridis in the Indo-Pacific region (FAO 2017) and $P$. perna in the tropics, subtropics and, recently, Gulf of Mexico (GISD 2019). Although these are cultivated or harvested in many countries, knowledge of disease occurrence and susceptibility is sparse (Vakily 1989, Lasiak 1993, Kaehler \& McQuaid 1999, da Silva et al. 2002, Galvao et al. 2015, FAO 2017).

In the absence of data, a precautionary approach assumes that pathogens of closely related cultured or wild bivalves are also potential hazards to the GLM. Pathogen exchange between the GLM and M. galloprovincialis (or closely related shellfish) is therefore plausible, given that, of the 17 main agents recorded in GLMs, 15 also occur in M. galloprovincialis, 9 in Crassostrea gigas and 10 in Ostrea chilensis in New Zealand (Table 1a). Host shifting by pathogens could be enabled by a number of drivers, including host relatedness, geographic overlap, changes in hostenvironment interactions and disease ecology, and anthropogenic factors (Peeler \& Feist 2011, Engering et al. 2013).

It is of particular interest whether the GLM might be susceptible to organisms that are not found in New Zealand but which cause mortalities in wild or cultured $M$. edulis species complex overseas, including in the Mediterranean mussel M. galloprovincialis (Villalba et al. 1993, Pérez Camacho et al. 1997, Krishnakumar et al. 1999, Rayyan et al. 2006, Romero et al. 2014). Of at least 6 significant disease agents that have been described for Mytilus spp. internationally, none has yet been recorded in New Zealand (Table 1b). However, evidence of ongoing human-mediated transport of Mytilus spp. into New Zealand from the Northern Hemisphere (Gardner et al. 2016) raises the possibility of new arrivals introducing exotic pathogens to which the GLM is susceptible (Rayyan et al. 2006). 


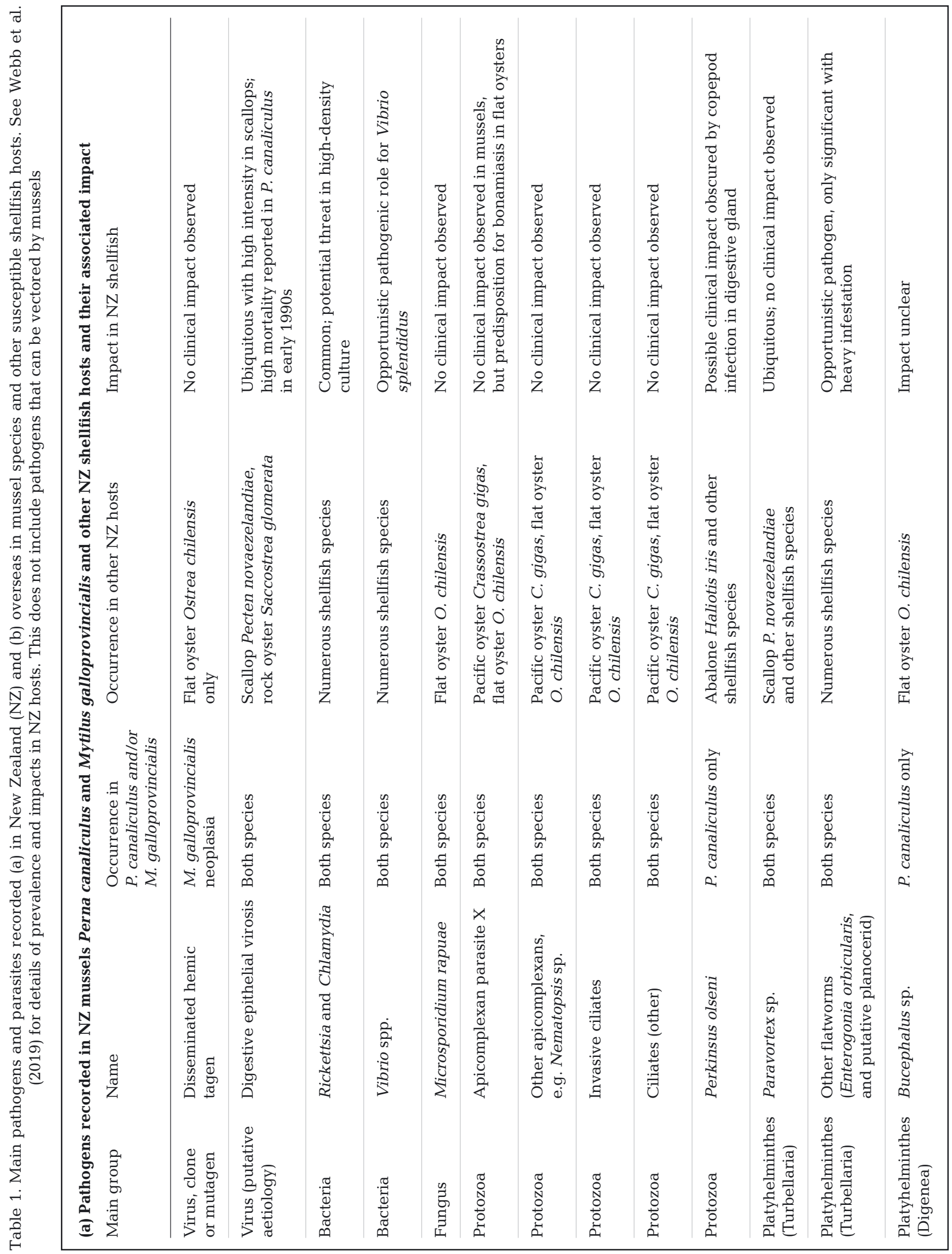




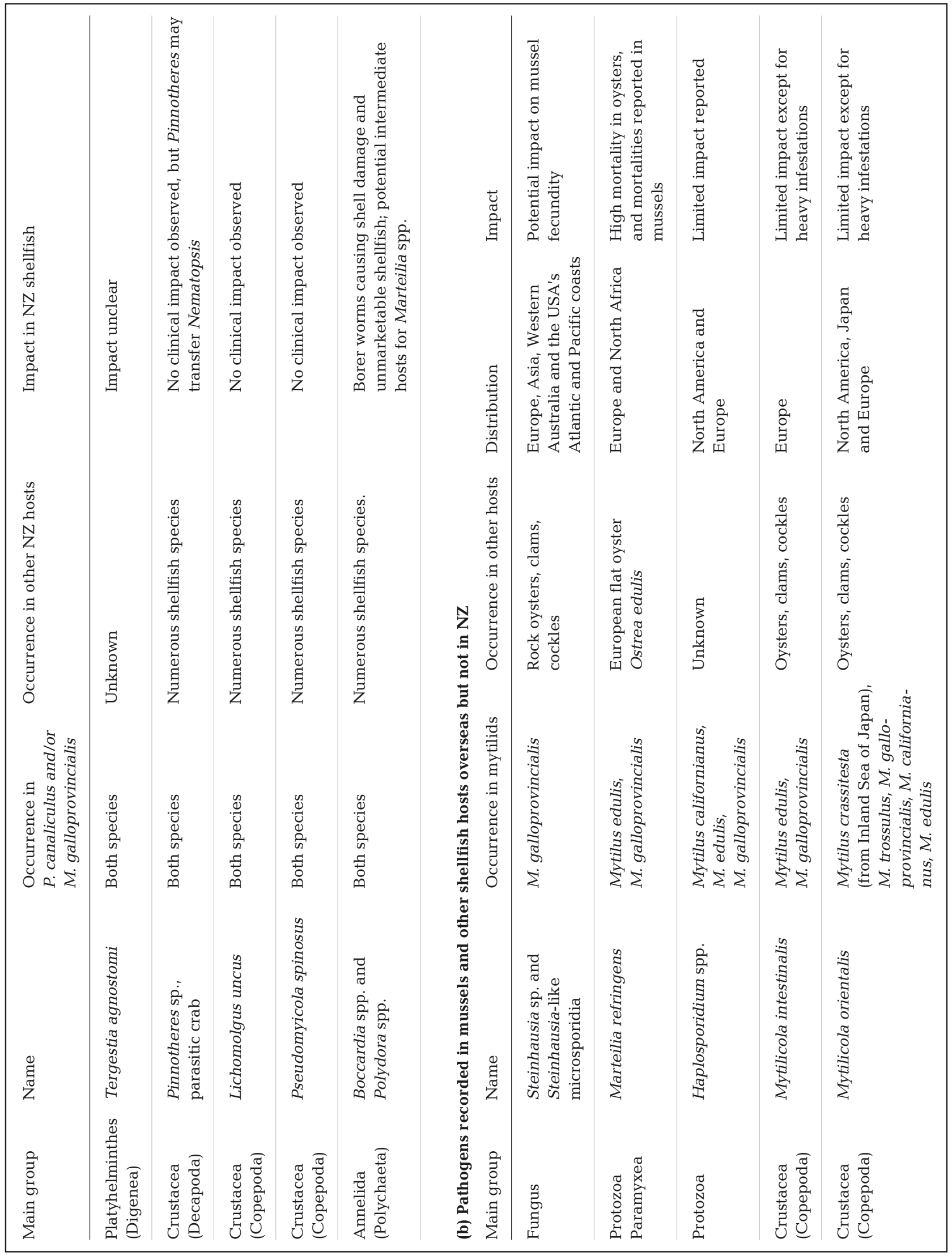

Table 1 continued 
Therefore, in New Zealand, M. galloprovincialis has the potential to become a significant reservoir of mytilid pathogens to which GLMs would be exposed, given the overlapping distribution of the 2 species and their co-occurrence on GLM farms. A further complication in the scenario of pathogen transfer from Mytilus spp. to GLMs is that hybridisation of local $M$. galloprovincialis with Mytilus introduced from the Northern Hemisphere could be a risk factor to disease susceptibility (Fuentes et al. 2002). M. edulis $\times$ M. galloprovincialis hybrids have already been identified on New Zealand's sub-Antarctic Auckland Islands (Westfall \& Gardner 2010).

Understanding the susceptibility of the GLM to existing or new pathogens and parasites is problematic. Experimental challenge models (e.g. López Sanmartín et al. 2016) may provide a way to explore the susceptibility of the GLM to certain pathogens affecting host species overseas. For existing disease agents of the GLM, or those found in other New Zealand shellfish, stress challenge tests (e.g. temperature or salinity stress) conducted in a laboratory may provide an avenue to determine the conditions under which clinical adverse effects might emerge. However, there are significant barriers to developing a suitable broad-spectrum challenge model for exotic disease agents. First, research with exotic pathogens would require experiments to be confined to high-level biocontainment facilities, after approval for importation under the relevant legislation. In the case of the parasite Marteilia refringens, which has been identified as a potential threat to the GLM (see Table 1b), laboratory experimental findings will not reliably reflect GLM susceptibility under natural conditions as the parasite has an indirect life cycle that requires an as yet unidentified intermediate host (Audemard et al. 2004). Ideally, the GLM needs to be exposed to environmental settings where the agent and intermediate host (where relevant) are present. Such research would require sending GLM samples overseas, where it is considered a non-indigenous species, but this would likely be prevented by regulatory barriers.

Adding to the absence of reliable and realistic experimental challenge models, the often elusive information on pathogen ecology and shellfish disease epidemiology considerably constrains hazard assessment for disease threats to the GLM.

\subsection{Challenges for consequence assessment}

Significant production and economic losses incurred by disease (e.g. reduced growth, decreased marketable value or widespread mortalities) are often mentioned during outbreaks, but there are very few detailed quantitative assessments (Castinel et al. 2014). The potential consequences of aquatic diseases are as challenging to forecast as their likelihood of occurrence. For example, discovery of Perkinsus olseni in farmed GLMs in the South Island of New Zealand during routine stock health assessment in 2014 was not unexpected, as this parasite has a wide host range globally, including New Zealand's North Island (Hine \& Diggles 2002). Infection with $P$. olseni is known to cause mortality in clam and Australian cultured greenlip abalone. In this instance, the discovery of $P$. olseni in the South Island appeared to be a simple range extension within New Zealand, with no apparent impact on GLM stocks. Nonetheless, this situation raises the issue of the GLM acting as a vector or reservoir for pathogens causing disease in other shellfish.

Indirect impacts of shellfish disease can be significant for the mussel farming industry, even when outbreaks occur in a different species. For example, although GLMs are not susceptible to the flat oyster parasite Bonamia ostreae, they may act as a vector, as can any shellfish species growing in an infected area (Culloty \& Mulcahy 2007, Mortensen et al. 2007, Peeler et al. 2011). As such, following an outbreak of this parasite in farmed flat oysters $O$. chilensis in New Zealand in 2015, restrictions on movements of farmed GLM from infected regions were introduced to minimise the risk of inadvertent $B$. ostreae spread to wild flat oyster fisheries (MPI 2018).

Consequence assessment is made particularly complex and uncertain by the fluctuations of environmental factors that influence host-agent interactions and disease emergence in new hosts or in new regions. Likewise there is no reason why the same environmental variations could not also disrupt parasitic lifecycles and reduce disease incidence. Disease transmission, pathogenicity and virulence may be enhanced by changes in environmental parameters, e.g. sea temperature and salinity (Sheehan \& Power 1999, Groner et al. 2016, Stephens et al. 2016). Warmer seas can modify the behaviour of pathogenic organisms and their interactions with the environment, for example by increasing host susceptibility to disease or providing conditions (e.g. nutrient enrichment) favourable to opportunistic agents (Harvell et al. 1999, Johnson et al. 2010). Though most significant effects documented to date are for larval stages, ocean acidification, due to humaninduced increases in atmospheric carbon dioxide, has already detrimentally affected the composition of 
calcium carbonate shells of mussels and other shellfish (Barton et al. 2015, Wahl et al. 2018). There are already signs that open ocean waters off New Zealand are acidifying, suggesting that coastal shellfish species could become more vulnerable to environmental stressors (Capson \& Guinotte 2014). However, in the short to medium term, coastal and estuarine animal populations are far more likely to be stressed or impacted by local anthropogenic activities in adjacent catchments, such as freshwater runoff or sedimentation from land deforestation (Diggles 2013, Knowles et al. 2014). Those events are already taking place along New Zealand coasts, which could contribute to the emergence of opportunistic pathogens that undermine the health of wild and cultured shellfish.

The epidemiology of aquatic diseases is a highly dynamic field which would greatly benefit from systematic environmental monitoring studies and investigations of mortalities, especially in production areas. Assuming that there are disease agents to which GLMs are susceptible, understanding the generic risk factors that may predispose this species to disease is highly relevant to consequence assessment.

\section{RISK PATHWAYS FOR THE SPREAD OF DISEASE AGENTS: NEW ZEALAND CONTEXT}

\subsection{International risk pathways for exotic agents}

Pathways for the introduction and spread of aquatic diseases are poorly understood. Potential mechanisms for the introduction of mussel pathogens and parasites to New Zealand (and subsequent spread within the country) are shown in Fig. 2. New Zealand's isolation means that anthropogenic activities

\section{INTERNATIONAL ENTRY MECHANISMS}

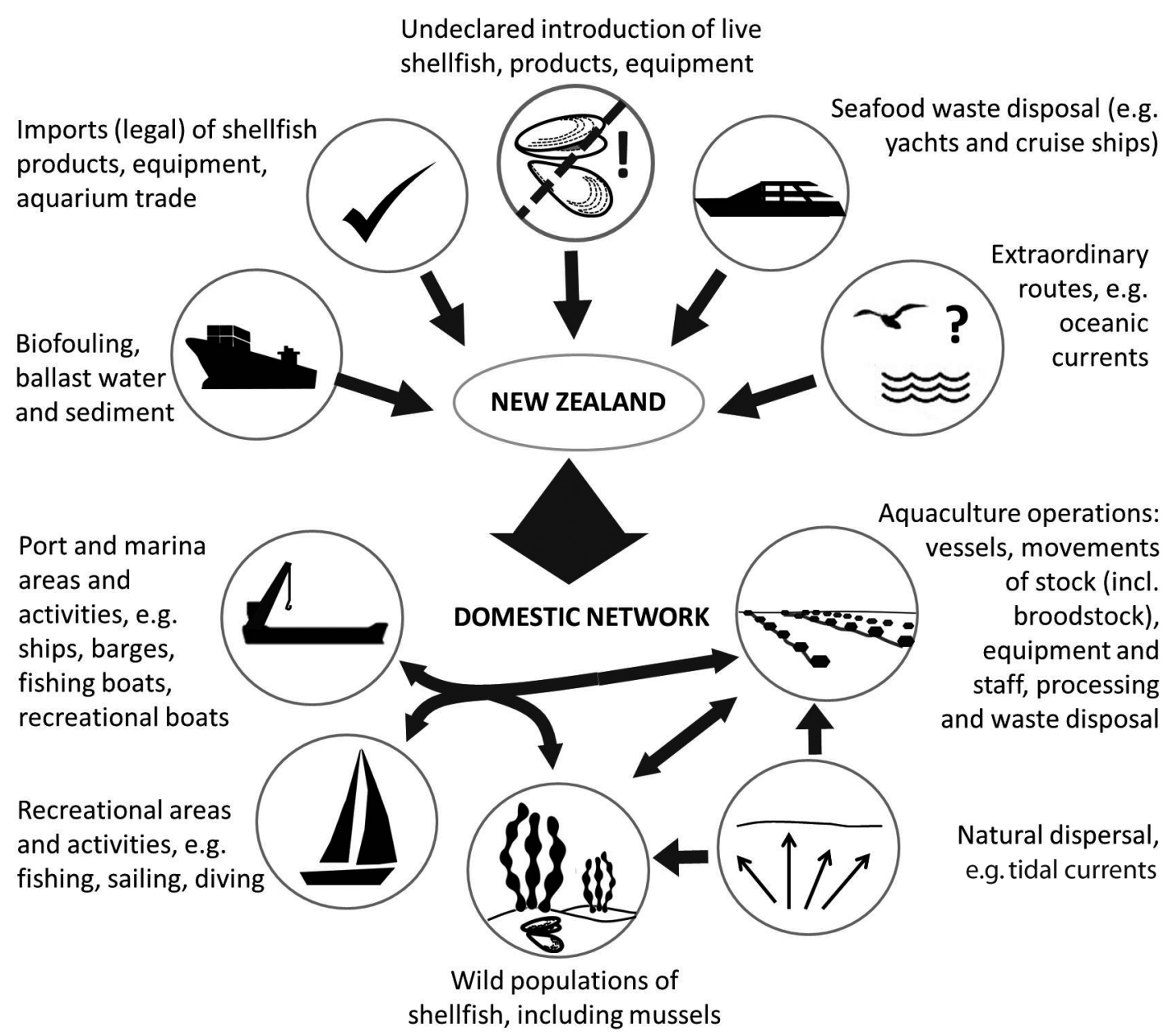

Fig. 2. Main types of international risk pathways for mussel pathogens and parasites into New Zealand, and major features of the domestic network that may interact with aquaculture 
provide the most plausible pathways for the initial incursion of exotic agents (Hewitt \& Campbell 2007), with natural pathways (e.g. ocean currents) expected to be relatively unimportant. For example, longdistance transmission of most infectious organisms is likely curbed by the limited persistence of free-living microbial particles outside the host (Murray 2013, Mojica \& Brussaard 2014). Nonetheless, migratory animals such as turtles and seabirds could play a role in the natural dispersal of pathogens and parasites (Hayward 1997, Steele et al. 2005, Thieltges et al. 2013). Rafting of floating debris covered with biofouling was inferred as the most likely scenario for the trans-Pacific range extension of the flat oyster Ostrea chilensis from New Zealand to Chile (Foighil et al. 1999), and this potential risk pathway was closely monitored when debris from the 2011 Japanese tsunami washed ashore in Hawaii and the northwestern USA (NOAA 2015).

In terms of anthropogenic spread, translocation of live aquatic animals (or associated equipment) to support aquaculture growth has been one of the most significant risk pathways globally (Minchin 2007, FAO 2012). For example, Bonamia ostreae emerged as a new parasite causing significant disease outbreaks in the European flat oyster O. edulis after spat was introduced from North America to restock native populations in Europe (Bishop et al. 2006, Peeler et al. 2011). In New Zealand, the importation of live shellfish for aquaculture or human consumption is currently not permitted. Similarly, shellfish products and equipment used for aquaculture or for other aquatic activities can only be imported under strict sanitary and phytosanitary requirements. However, the volumes of (inadvertently or willingly) undeclared goods intercepted at the border during inspection (MPI 2017) are a reminder that illegal introductions cannot be ignored as an entry mechanism.

The predominant pathway for the introduction of new aquatic organisms into New Zealand is likely to be the ongoing arrivals of international vessels (Hewitt et al. 2004). A range of vessel types have been implicated in the inadvertent spread of new species to New Zealand. These include merchant ships, cruise ships, fishing vessels, recreational boats and towed structures such as barges and drilling platforms (Foster \& Willan 1979, Floerl et al. 2005, Coutts \& Forrest 2007, Dodgshun et al. 2007, Hayden et al. 2009, Hopkins \& Forrest 2010a,b). Associated mechanisms include hull biofouling (Bell et al. 2011), the discharge of ballast water and associated sediments (Carlton 1985, Hayward 1997, Taylor et al. 2007) and the transfer of mobile organisms (e.g. crabs, sea stars) in recesses such as the sea chests of large vessels (Coutts \& Dodgshun 2007, Frey et al. 2014).

Biofouling is undisputed as a significant mechanism for the transfer of bivalves and other macrofouling organisms across long distances; the introduction of infected shellfish via this mechanism is the most likely risk pathway for the transport of new disease agents to New Zealand. Many of the globally important cultured shellfish species that have experienced disease in a farming environment are also common biofouling organisms (Minchin \& Gollasch 2003, Hewitt et al. 2009). Studies of vessels arriving in New Zealand have revealed the presence of Mytilus galloprovincialis, Crassostrea and Ostrea species and exotic Perna species (Hopkins \& Forrest 2010a,c). Biofouling species may be direct hosts for pathogens or parasites (e.g. infected oysters or mussels) or may act as asymptomatic carriers or intermediate hosts (Tan et al. 2002, Peoples 2013). However, there is only limited evidence to support the association between biofouling and disease incursions. A survey using molecular and histopathology techniques screened for target pathogens (B. exitiosa, B. ostreae, Perkinsus marinus, $P$. olseni, Marteilia refringens, Haplosporidium nelsoni) in 1500 molluscs sampled over 3 yr from New Zealand international ports (Gias $\&$ Johnston 2010). No exotic shellfish pathogens were identified, but pathogens already in New Zealand such as $B$. exitiosa and Microsporidium rapuae were present in biofouling molluscs. Similarly, the role of ballast water and sediment in transferring microbes has been demonstrated for human pathogens such as Vibrio spp. but has yet to be proven for disease agents of aquatic animals (Ruiz et al. 2000, Drake et al. 2007).

The recent implementation in New Zealand of a Craft Risk Management Standard (CRMS) for managing biofouling on international vessel arrivals (MPI 2014) is likely to lead to a major reduction in the ongoing risk of biofouling. The CRMS promotes best practice to minimise fouling on submerged surfaces of vessels arriving in New Zealand. A clean hull is required, for which the allowable biofouling is constrained to goose barnacles and a low coverage of globally cosmopolitan taxa such as bryozoans and barnacles. In terms of risk to shellfish aquaculture, compliance with the CRMS means that a vessel would not be allowed into New Zealand waters if it harboured molluscs on its hull. In practice, some residual risk is almost certain due to fouling by molluscs and other organisms in the niche areas of large vessels (Coutts \& Dodgshun 2007). These include sea 
chests and other hull locations that are prone to fouling, hard to inspect or difficult to effectively treat inwater (Lewis \& Dimas 2007, Growcott et al. 2017).

\subsection{Domestic risk pathways}

As risks from international pathways cannot be completely eliminated, there remains the need for an ongoing focus on internal biosecurity and management of domestic borders. Key pathways for the domestic spread of disease agents in New Zealand are similar to the international ones (Dodgshun et al. 2007) but are more varied in terms of the range of anthropogenic activities (Fig. 2). Of particular relevance are mussel industry transfers, since GLM spat and seed are routinely transported between growing regions (Forrest \& Blakemore 2006) with no quarantine period. These movements carry the potential to transfer disease or disease agents with infected stock or with entrained biofouling, water or sediments (Murray 2013). In the event of an infectious disease incursion in a spat-producing region, the infection could spread very rapidly throughout the industry, unless domestic pathway controls were implemented quickly or were already in place.

Disease spread via stock movements in New Zealand was illustrated in 2010 during the first series of mortality outbreaks in Pacific oysters associated with the OsHV-1 microvar, in which spat losses of ca. $90 \%$ were recorded (Bingham et al. 2013, Castinel et al. 2015). In most cases, infected stock continued to be transferred to areas where there were no observed mortalities (in an attempt to keep stock alive), with subsequent disease outbreaks in the recipient areas. Movements of equipment and barges from affected areas to other parts of the country may have also contributed to the spread of virus, as sharing equipment between shellfish farms is the second most important source of risk after movements of infected stock (Peeler et al. 2007).

Non-industry pathways are also likely to be of significance in the domestic spread of disease agents. In particular, recreational vessels are considered a significant risk pathway for the spread of biofouling organisms and, by association, potentially infectious agents. Other contributing mechanisms could include the transport of potentially harmful organisms in vessel bilge water (Fletcher et al. 2017, Pochon et al. 2017) and the transfer of recreational equipment among water bodies (Sinner et al. 2013). Additionally, and by contrast with international transfers, natural dispersal is likely to be relatively important at domestic scales. As most aquatic pathogens have a horizontal transmission (i.e. by contact), dispersal in the water column (e.g. through tidal currents) is likely to play a significant role in the local spread of disease (Whittington et al. 2018), especially in areas with a high density of farms in close proximity (Murray 2013, Pernet et al. 2016). Furthermore, since most shellfish aquaculture operations in New Zealand are open water systems, it is reasonable to assume that an organism newly established in wild populations will eventually spread to adjacent or related farmed stocks and vice versa (Peeler et al. 2011). The GLM aquaculture industry is tightly connected, and growing areas overlap with non-industry activities and corridors. Additionally, there are still considerable knowledge gaps and areas of uncertainty with respect to critical points for those risk pathways, which makes area-wide management of potentially harmful organisms even more challenging (Table 2).

Development of effective preventative and control strategies to address pathway risk is therefore problematic. New Zealand does not yet have any comprehensive national action plan to manage domestic pathways for the spread of potentially harmful aquatic organisms. The aquaculture industry has developed operational guidelines to encourage best management practices for biosecurity (AQNZ 2016), for example to improve reporting procedures for better traceability of stock movements or to manage risks from biofouling and entrained water (e.g. bilge water) or sediments. Yet, in spite of these guidelines, most aquaculture companies seem reluctant to plan for and implement proactive risk-reduction measures (Castinel et al. 2015, Sim-Smith et al. 2016).

\section{A WAY FORWARD?}

Until 2010, there was a perception that the New Zealand shellfish aquaculture industry was largely immune to disease threats. This was based on presumed resilience to diseases for the 2 main culture species (GLMs and Pacific oysters) and a view that New Zealand's geographic isolation conferred some level of protection against biosecurity incursions. However, the emergence of the OsHV-1 microvar in Pacific oysters in 2010 and Bonamia ostreae in flat oysters in 2015 with associated important socioeconomic impacts in aquaculture, began to challenge that perception and has reinforced the need for better biosecurity practices.

Despite the wake-up calls experienced by Pacific and flat oyster industry sectors and improved under- 
Table 2. Pathways for introduction and establishment of a new disease agent of green-lipped mussels (GLM) in New Zealand (NZ): critical steps, contributing factors and related uncertainties

\begin{tabular}{|c|c|}
\hline Critical point & Contributing factors and related uncertainties \\
\hline Introduction into NZ & $\begin{array}{l}\text { - Lack of knowledge on likelihood of agent uptake in source region, transport survival } \\
\text { and release in recipient region (NZ) } \\
\text { - Poor understanding of the role of biofouling, water (e.g. ballast water) and sediments } \\
\text { in vectoring pathogens or parasites }\end{array}$ \\
\hline $\begin{array}{l}\text { Agent establishment in } \\
\text { recipient environment/host }\end{array}$ & $\begin{array}{l}\text { - Lack of effective tools for detection, eradication and containment of new agent } \\
\text { - Host range and reservoirs poorly understood, and susceptibility to potential exotic } \\
\text { agents unknown } \\
\text { - Uncertainty regarding pathogen exchange between hosts as well as the identity of } \\
\text { intermediate hosts }\end{array}$ \\
\hline $\begin{array}{l}\text { Domestic spread of agent } \\
\text { to wild or cultured mussels }\end{array}$ & $\begin{array}{l}\text { - Limited understanding and inherent variability of natural dispersal processes and } \\
\text { domestic anthropogenic pathway risk } \\
\text { - Absence of or ineffective preventative measures within aquaculture industry or for } \\
\text { other risk pathways }\end{array}$ \\
\hline $\begin{array}{l}\text { Disease occurrence in wild } \\
\text { or cultured mussels }\end{array}$ & $\begin{array}{l}\text { - Proximity of wild mussels or reservoir hosts to cultured GLM } \\
\text { - Poor understanding of environmental risk factors (e.g. temperature) and role of on-farm } \\
\text { practices (e.g. stocking density) in triggering disease outbreaks }\end{array}$ \\
\hline $\begin{array}{l}\text { Spread of disease among } \\
\text { aquaculture facilities, sites } \\
\text { or regions }\end{array}$ & $\begin{array}{l}\text { - Absence of or ineffective biosecurity controls in production systems (e.g. hatchery or } \\
\text { grow-out sites) and processing facilities (and associated wastewater discharge) } \\
\text { - Lack of record-keeping for traceability or movement controls for actual or potential risk } \\
\text { pathways (e.g. equipment, stock transfers) }\end{array}$ \\
\hline
\end{tabular}

standing of potential risks and management opportunities in New Zealand (AQNZ 2016, Georgiades et al. 2016, MPI 2016), the GLM industry remains highly vulnerable to new incursions or emergence of diseases, and there is little evidence of industry strengthening their biosecurity practices. Genomics have shown that considerable improvements can be made to control diseases in livestock, and selective breeding has been deemed a key management tool to control diseases in shellfish (Hollenbeck \& Johnston 2018). More scientific evidence is still needed to demonstrate the net contribution of selective breeding to disease resistance in shellfish. There are also some caveats to consider, for example the need to manage inbreeding and ensure that the genetic diversity of germplasm is preserved. In addition, the effectiveness of selective breeding for resistance to disease varies with its epidemiology and with the biology of the pathogen or parasite (Bishop \& Woolliams 2014).

As highlighted in this paper, there is a fundamental lack of scientific knowledge around aquatic disease risk to the GLM in the New Zealand context. This could be stated more broadly for aquaculture species found in a limited geographic range and/or cultured in areas where there is little, if any, exposure to aquatic diseases. This type of baseline information is essential to the development of effective animal health strategies and policies, and a new approach is required to progress risk assessment and management of aquatic diseases (Pernet et al. 2016).

Addressing some of the key uncertainties regarding disease threats to farmed mussels in New Zealand requires considerable fundamental research across biological, ecological and social areas. This would not only help fill critical knowledge gaps, but also increase confidence in the basis for risk management interventions. These considerations are valid beyond New Zealand borders, and priorities for future work in aquatic animal health should focus on improving our understanding of risk factors and our ability to predict disease outbreaks to prevent them or at least limit their impacts (Pernet et al. 2016). To enable better prediction and understanding of hostenvironment-disease agent interactions, epidemiological studies will be critical to understand emerging disease patterns and drivers at the host population level (Audemard et al. 2004, Subasinghe 2005, Engelsma et al. 2010, Peeler et al. 2012, Paul-Pont et al. 2013). Such studies remain complex for the GLM, but a start would be to explore conducting research overseas on suitable surrogate species (e.g. a Perna species). New Zealand scientists could also collaborate on research projects seeking to elucidate the life cycle of mussel parasites where disease occurs. This would help refine New Zealand's risk assessment for some exotic mussel parasites. Cost-effective detection and monitoring tools are also becoming increas- 
ingly needed to collect real-time data on both environmental parameters and stock health. Deploying sentinels at high-risk sites could reduce the time lapse between incursion and overt signs of diseases on farms (Rodríguez-Prieto et al. 2015). Sentinels could include species that are known to be susceptible hosts to pests or pathogens of mussels overseas. Innovative surveillance technologies using molecular diagnostic methods are showing encouraging results (Gias \& Johnston 2010, Pochon et al. 2013), but they need to be firmly grounded in the basic biology of the pathogen and its host. Early warning systems are also needed, including regular systematic surveys of farmed and wild shellfish populations.

Predictive models for regional-scale disease spread, based on both anthropogenic pathways and natural dispersal (e.g. using particle dispersion models, network analysis), will inform the development of areabased management strategies and identify where management of aquaculture and other anthropogenic risk pathways are likely to have the greatest impact (Forrest et al. 2009, Salama \& Rabe 2013, Pernet et al. 2016, Samsing et al. 2017). Where uncertainty remains, including when quantifying domestic risk pathways and prioritising interventions, robust processes for risk assessment and expert judgement (e.g. Burgman 2005) should be considered to better characterise the likelihoods and consequences of the events that lead to disease outbreaks.

With a changing marine environment and the prospect of new disease threats, it is timely for the aquaculture industry world-wide to secure its future and the sustainability of its production by tackling animal health challenges. In New Zealand, the GLM farming industry is currently leading the aquaculture sector in terms of production volumes and export revenue. It is in good standing to influence behaviours and perceptions across the country's aquaculture companies by improving risk management policies and decisions to minimise impacts of disease outbreaks on industry, environment and people. As part of achieving this outcome, industry support of multidisciplinary research that integrates ecological, epidemiological, cultural and socioeconomic data is critical (Pernet et al. 2016). The development of science-based solutions, however, requires open communication and collaboration between industry, the regulators, Māori and the wider community. Most importantly, the accountability for biosecurity and for aquatic environmental health must be shared and supported by all parties, which represents both a challenge and an opportunity for New Zealand.
Acknowledgements. The authors thank Cara Brosnahan, Henry Lane and Eugene Georgiades from New Zealand's Ministry for Primary Industries for their comments on a draft manuscript. This research was undertaken under funding from the New Zealand Ministry of Business, Innovation and Employment, contract CAW1315 (Enabling, Growing and Securing New Zealand's Shellfish Aquaculture Sector).

\section{LITERATURE CITED}

AQNZ (Aquaculture New Zealand) (2016) Sustainable management framework: New Zealand mussels. www. aplusaquaculture.nz/farmers-information/ (accessed 18 May 2018)

Audemard C, Sajus MC, Barnaud A, Sautour B, Sauriau PG, Berthe FJC (2004) Infection dynamics of Marteilia refringens in flat oyster Ostrea edulis and copepod Paracartia grani in a claire pond of Marennes-Oleron Bay. Dis Aquat Org 61:103-111

* Barton A, Waldbusser GG, Feely RA, Weisberg SB and others (2015) Impacts of coastal acidification on the Pacific Northwest shellfish industry and adaptation strategies implemented in response. Oceanography (Wash DC) 28: 146-159

Bell A, Phillips S, Georgiades E, Kluza D, Denny C (2011) Risk analysis: vessel biofouling. Ministry of Agriculture and Forestry, Wellington

Bingham P, Brangenberg N, Williams R, van Andel M (2013) Investigation into the first diagnosis of ostreid herpesvirus type 1 in Pacific oysters. Surveillance 40:20-24

* Bishop SC, Woolliams JA (2014) Genomics and disease resistance studies in livestock. Livest Sci 166:190-198

Bishop MJ, Carnegie RB, Stokes NA, Peterson CH, Burreson EM (2006) Complications of a non-native oyster introduction: facilitation of a local parasite. Mar Ecol Prog Ser 325:145-152

Burgman M (2005) Risks and decisions for conservation and environmental management. Ecology, Biodiversity and Conservation Series. Cambridge University Press, Cambridge

Capson TL, Guinotte J (2014) Future proofing New Zealand's shellfish aquaculture: monitoring and adaptation to ocean acidification. New Zealand Aquatic Environment and Biodiversity Rep No. 136. Ministry for Primary Industries, Wellington

Carlton JT (1985) Transoceanic and interoceanic dispersal of coastal marine organisms: the biology of ballast water. Oceanogr Mar Biol Annu Rev 23:313-371

Castinel A, Forrest B, Hopkins G (2014) Review of diseases of potential concern for New Zealand shellfish aquaculture: perspectives for risk management. Cawthron Rep No. 2297. https://www.cawthron.org.nz/publications/sciencereports/

Castinel A, Fletcher L, Dhand N, Rubio A, Whittington RJ, Taylor M (2015) OsHV-1 mortalities in Pacific oysters in Australia and New Zealand: the farmer's story. Cawthron Rep No. 2567. https://www.cawthron.org.nz/publications/ science-reports/

Coutts ADM, Dodgshun TJ (2007) The nature and extent of organisms in vessel sea-chests: a protected mechanism for marine bioinvasions. Mar Pollut Bull 54:875-886

Coutts ADM, Forrest BM (2007) Development and application of tools for incursion response: lessons learned from the management of the fouling pest Didemnum vexillum. J Exp Mar Biol Ecol 342:154-162 
Culloty SC, Mulcahy MF (2007) Bonamia ostreae in the native oyster Ostrea edulis. A review. Marine and Environmental Health Series 29. Marine Institute, Dublin

da Silva PM, Magalhaes ARM, Barracco MA (2002) Effects of Bucephalus sp. (Trematoda: Bucephalidae) on Perna perna mussels from a culture station in Ratones Grande Island, Brazil. J Invertebr Pathol 79:154-162

Diggles BK (2013) Historical epidemiology indicates water quality decline drives loss of oyster (Saccostrea glomerata) reefs in Moreton Bay, Australia. N Z J Mar Freshw Res 47:561-581

* Dodgshun TJ, Taylor MD, Forrest BM (2007) Humanmediated pathways of spread for nonindigenous marine species in New Zealand. DOC Research and Development Series 266. Department of Conservation. https://www.doc. govt.nz/documents/science-and-technical/drds266.pdf

Norake LA, Doblin MA, Dobbs FC (2007) Potential microbial bioinvasions via ships' ballast water, sediment, and biofilm. Mar Pollut Bull 55:333-341

Engelsma MY, Kerkhoff S, Roozenburg I, Haenen OLM and others (2010) Epidemiology of Bonamia ostreae infecting European flat oysters Ostrea edulis from Lake Grevelingen, The Netherlands. Mar Ecol Prog Ser 409:131-142

Engering A, Hogerwerf L, Slingenbergh J (2013) Pathogen-host-environment interplay and disease emergence. Emerg Microbes Infect 2:e5

Evans B (2006) The social and political impact of animal diseases. Vet Ital 42:399-406

FAO (2012) Introduction of species. FAO Fisheries and Aquaculture. www.fao.org/fishery/topic/13532/en (accessed 26 Apr 2018)

FAO (2015) Global aquaculture production statistics database updated to 2013: summary information. FAO Fisheries and Aquaculture. www.fao.org/3/a-i4899e.pdf

FAO (2017) Species fact sheets: Perna viridis (Linnaeus, 1758). FAO Fisheries and Aquaculture. www.fao.org/ fishery/species/2691/en (accessed 24 May 2018)

Fletcher LM, Zaiko A, Atalah J, Richter I and others (2017) Bilge water as a vector for the spread of marine pests: a morphological, metabarcoding and experimental assessment. Biol Invasions 19:2851-2867

F Floerl O, Inglis GJ, Hayden BJ (2005) A risk-based predictive tool to prevent accidental introductions of nonindigenous marine species. Environ Manage 35:765-778

Foighil DO, Marshall BA, Hilbish TJ, Pino MA (1999) TransPacific range extension by rafting is inferred for the flat oyster Ostrea chilensis. Biol Bull 196:122-126

Forrest BM, Atalah J (2017) Significant impact from blue mussel Mytilus galloprovincialis biofouling on aquaculture production of green-lipped mussels in New Zealand. Aquacult Environ Interact 9:115-126

Forrest BM, Blakemore KA (2006) Evaluation of treatments to reduce the spread of a marine plant pest with aquaculture transfers. Aquaculture 257:333-345

Forrest BM, Gardner JPA, Taylor MD (2009) Internal borders for managing invasive marine species. J Appl Ecol 46:46-54

Foster BA, Willan RC (1979) Foreign barnacles transported to New Zealand on an oil platform. N Z J Mar Freshw Res 13:143-149

Frey MA, Simard N, Robichaud DD, Martin JL, Therriault TW (2014) Fouling around: vessel sea-chests as a vector for the introduction and spread of aquatic invasive species. Manag Biol Invasion 5:21-30

Fuentes J, López JL, Mosquera E, Vázquez J, Villalba A,
Álvarez G (2002) Growth, mortality, pathological conditions and protein expression of Mytilus edulis and $M$. galloprovincialis crosses cultured in the Ría de Arousa (NW of Spain). Aquaculture 213:233-251

Galvao P, Longo R, Torres JPM, Malm O (2015) Estimating the potential production of the brown mussel Perna perna (Linnaeus, 1758) reared in three tropical bays by different methods of condition indices. J Mar Biol 2015: 948053

Gardner JPA, Zbawicka M, Westfall KM, Wenne R (2016) Invasive blue mussels threaten regional scale genetic diversity in mainland and remote offshore locations: the need for baseline data and enhanced protection in the Southern Ocean. Glob Chang Biol 22:3182-3195

*Georgiades E, Fraser R, Jones B (2016) Options to strengthen on-farm biosecurity management for commercial and non-commercial aquaculture. Tech Pap No. 2016/47. Ministry for Primary Industries. https://www.mpi.govt.nz/ dmsdocument/13287/send

Gias E, Johnston C (2010) Molecular tools for diagnosis of mollusc pathogens. Surveillance 37:44-48

* Global Invasive Species Database (2019) Species profile: Perna perna. www.iucngisd.org/gisd/species.php?sc=742 (accessed 4 Apr 2019)

* Groner ML, Maynard J, Breyta R, Carnegie RB and others (2016) Managing marine disease emergencies in an era of rapid change. Philos Trans R Soc B 371:20150364

*Gowcott A, Kluza D, Georgiades E (2017) Review: in-water systems to reactively manage biofouling in sea chests. Mar Technol Soc J 51:89-104

Harvell CD, Kim K, Burkholder JM, Colwell RR and others (1999) Emerging marine diseases - climate links and anthropogenic factors. Science 285:1505-1510

Hayden BJ, Inglis GJ, Schiel DR (2009) Marine invasions in New Zealand: a history of complex supply-side dynamics. In: Rilov G, Crooks JA (eds) Biological invasions in marine ecosystems: ecological, management, and geographic perspectives, Book 204. Springer-Verlag, Berlin, p 409-423

Hayward B (1997) Introduced marine organisms in New Zealand and their impact in the Waitemata Harbour, Auckland. Tane 36:197-223

Hedrick RP (1996) Movement of pathogens with the international trade of live fish: problems and solutions. Rev Sci Tech 15:523-531

*Hewitt CL, Campbell ML (2007) Mechanisms for the prevention of marine bioinvasions for better biosecurity. Mar Pollut Bull 55:395-401

Hewitt CL, Willing J, Bauckham A, Cassidy AM, Cox CMS, Jones L, Wotton DM (2004) New Zealand marine biosecurity: delivering outcomes in a fluid environment. N Z J Mar Freshw Res 38:429-438

Hewitt CL, Gollasch S, Minchin D (2009) The vessel as a vector-biofouling, ballast water and sediments. In: Rilov G, Crooks JA (eds) Biological invasions in marine ecosystems: ecological, management, and geographic perspectives, Book 204. Springer, Berlin

Hine PM (2002) Results of a survey on shellfish health in New Zealand in 2000. Surveillance 29:3-7

Hine PM, Diggles B (2002) The distribution of Perkinsus olseni in New Zealand bivalve molluscs. Surveillance 29: 8-11

*Hollenbeck CM, Johnston IA (2018) Genomic tools and selective breeding in molluscs. Front Genet 9:253

Hopkins GA, Forrest BM (2010a) Challenges associated 
with pre-border management of biofouling on oil rigs. Mar Pollut Bull 60:1924-1929

Hopkins GA, Forrest BM (2010b) A preliminary assessment of biofouling and non-indigenous marine species associated with commercial slow-moving vessels arriving in New Zealand. Biofouling 26:613-621

Hopkins GA, Forrest BM (2010c) Vessel biofouling as a vector for the introduction of non-indigenous marine species to New Zealand: slow-moving barges and oil platforms. Tech Pap No. 2010/12. Prepared for MAF Biosecurity New Zealand. https://www.mpi.govt.nz/dms document/7332/send

Israngkura A, Sae-Hae S (2002) A review of the economic impacts of aquatic animal disease. In: Arthur JR, Phillips MJ, Subasinghe RP, Reantaso MB, MacRae IH (eds) Primary aquatic animal health care in rural, small-scale, aquaculture development. FAO Fish Tech Pap 406: 253-286

Johnson PTJ, Townsend AR, Cleveland CC, Glibert PM and others (2010) Linking environmental nutrient enrichment and disease emergence in humans and wildlife. Ecol Appl 20:16-29

Jones JB, Scotti PD, Dearing SC, Wesney B (1996) Virus-like particles associated with marine mussel mortalities in New Zealand. Dis Aquat Org 25:143-149

Kaehler S, McQuaid CD (1999) Lethal and sublethal effects of phototrophic endoliths attacking the shell of the intertidal mussel Perna perna. Mar Biol 135:497-503

Knowles G, Handlinger J, Jones B, Moltschaniwskyj N (2014) Hemolymph chemistry and histopathological changes in Pacific oysters (Crassostrea gigas) in response to low salinity stress. J Invertebr Pathol 121:78-84

Krishnakumar PK, Casillas E, Snider RG, Kagley AN, Varanasi U (1999) Environmental contaminants and the prevalence of hemic neoplasia (leukemia) in the common mussel (Mytilus edulis complex) from Puget Sound, Washington, USA. J Invertebr Pathol 73:135-146

Lasiak T (1993) Bucephalid trematode infections in the brown mussel Perna perna (Bivalvia: Mytilidae). S Afr J Mar Sci 13:127-134

Lewis JA, Dimas J (2007) Treatment of biofouling in internal seawater systems - phase 2. Tech Rep DSTO-TR-2081, Maritime Platforms Division, Defence Science and Technology Organisation, Department of Defence, Canberra

López Sanmartín M, Power DM, de la Herrán R, Navas JI, Batista FM (2016) Experimental infection of European flat oyster Ostrea edulis with ostreid herpesvirus 1 microvar (OsHV-1 $\mu$ var): mortality, viral load and detection of viral transcripts by in situ hybridization. Virus Res 217:55-62

Minchin D (2007) Aquaculture and transport in a changing environment: overlap and links in the spread of alien biota. Mar Pollut Bull 55:302-313

Minchin D, Gollasch S (2003) Fouling and ships' hulls: how changing circumstances and spawning events may result in the spread of exotic species. Biofouling 19:111-122

Mojica KDA, Brussaard CPD (2014) Factors affecting virus dynamics and microbial host-virus interactions in marine environments. FEMS Microbiol Ecol 89:495-515

Mortensen S, Arzul I, Miossec L, Paillard C and others (2007) Molluscs and crustaceans. In: Raynard RT, Wahli T, Vatsos I, Mortensen S (eds) Review of disease interactions and pathogen exchange between farmed and wild finfish and shellfish in Europe. VESO on behalf of DIPNET, Oslo
MPI (Ministry for Primary Industries) (2014) Craft Risk Management Standard: biofouling on vessels arriving to New Zealand. Ministry for Primary Industries, Wellington

MPI (2016) Aquaculture biosecurity handbook: assisting New Zealand's commercial and non-commercial aquaculture to minimise on-farm biosecurity risk. Ministry for Primary Industries, Wellington

MPI (2017) The border space. Newsletter, June 2017. www. mpi.govt.nz

*MPI (2018) Biosecurity New Zealand: protection and response - Bonamia ostreae. www.mpi.govt.nz/protectionand-response/responding/alerts/bonamia-ostreae/ (accessed 15 May 2018)

Murray AG (2013) Epidemiology of the spread of viral diseases under aquaculture. Curr Opin Virol 3:74-78

Murray AG, Peeler EJ (2005) A framework for understanding the potential for emerging diseases in aquaculture. Prev Vet Med 67:223-235

NOAA (2015) Detecting Japan tsunami marine debris at sea: a synthesis of efforts and lessons learned. NOAA Tech Memo NOS-OR\&R-51

* Oidtmann BC, Thrush MA, Denham KL, Peeler EJ (2011) International and national biosecurity strategies in aquatic animal health. Aquaculture 320:22-33

OIE (World Organisation for Animal Health) (2017) Import risk analysis. In: Aquatic animal health code. www.oie.int/ index.php?id=171\&L=0\&htmfile=chapitre_import_risk_ analysis.htm (accessed 9 Mar 2018)

* Paul-Pont I, Dhand NK, Whittington RJ (2013) Spatial distribution of mortality in Pacific oysters Crassostrea gigas: reflection on mechanisms of OsHV-1 transmission. Dis Aquat Org 105:127-138

* Peeler EJ, Feist SW (2011) Human intervention in freshwater ecosystems drives disease emergence. Freshw Biol 56:705-716

* Peeler EJ, Murray AG, Thebault A, Brun E, Giovaninni A, Thrush MA (2007) The application of risk analysis in aquatic animal health management. Prev Vet Med 81: 3-20

* Peeler EJ, Oidtmann BC, Midtlyng PJ, Miossec L, Gozlan RE (2011) Non-native aquatic animals introductions have driven disease emergence in Europe. Biol Invasions 13: 1291-1303

* Peeler EJ, Reese RA, Cheslett DL, Geoghegan F, Power A, Thrush MA (2012) Investigation of mortality in Pacific oysters associated with Ostreid herpesvirus-1 $\mu$ Var in the Republic of Ireland in 2009. Prev Vet Med 105:136-143

* Peoples RC (2013) A review of the helminth parasites using polychaetes as hosts. Parasitol Res 112:3409-3421

Pérez Camacho A, Villalba A, Beiras R, Labarta U (1997) Absorption efficiency and condition of cultured mussels (Mytilus edulis galloprovincialis Linnaeus) of Galicia (NW Spain) infected by parasites Marteilia refringens Grizel et al. and Mytilicola intestinalis Steuer. J Shellfish Res 16:77-82

* Pernet F, Lupo C, Bacher C, Whittington RJ (2016) Infectious diseases in oyster aquaculture require a new integrated approach. Philos Trans R Soc B 371:20150213

* Pochon X, Bott NJ, Smith KF, Wood SA (2013) Evaluating detection limits of next-generation sequencing for the surveillance and monitoring of international marine pests. PLOS ONE 8:e73935

* Pochon X, Zaiko A, Fletcher LM, Laroche O, Wood SA (2017) Wanted dead or alive? Using metabarcoding of environmental DNA and RNA to distinguish living 
assemblages for biosecurity applications. PLOS ONE 12: $\mathrm{e} 0187636$

Rayyan A, Damianidis P, Antoniadou C, Chintiroglou CC (2006) Protozoan parasites in cultured mussels Mytilus galloprovincialis in the Thermaikos Gulf (north Aegean Sea, Greece). Dis Aquat Org 70:251-254

Renault T, Stokes NA, Chollet B, Cochennec N, Berthe F, Gérard A, Burreson EM (2000) Haplosporidiosis in the Pacific oyster Crassostrea gigas from the French Atlantic coast. Dis Aquat Org 42:207-214

Rodríguez-Prieto V, Vicente-Rubiano M, Sánchez-Matamoros A, Rubio-Guerri C and others (2015) Systematic review of surveillance systems and methods for early detection of exotic, new and re-emerging diseases in animal populations. Epidemiol Infect 143:2018-2042

Romero A, Costa MdM, Forn-Cuni G, Balseiro P and others (2014) Occurrence, seasonality and infectivity of Vibrio strains in natural populations of mussels Mytilus galloprovincialis. Dis Aquat Org 108:149-163

Ruiz GM, Rawlings TK, Dobbs FC, Drake LA, Mullady T, Huq A, Colwell RR (2000) Global spread of microorganisms by ships: ballast water discharged from vessels harbours a cocktail of potential pathogens. Nature 408: 49-50

Salama NKG, Rabe B (2013) Developing models for investigating the environmental transmission of diseasecausing agents within open-cage salmon aquaculture. Aquacult Environ Interact 4:91-115

Samsing F, Johnsen I, Dempster T, Oppedal F, Treml EA (2017) Network analysis reveals strong seasonality in the dispersal of a marine parasite and identifies areas for coordinated management. Landsc Ecol 32:1953-1967

Segarra A, Pépin JF, Arzul I, Morga B, Faury N, Renault T (2010) Detection and description of a particular Ostreid herpesvirus 1 genotype associated with massive mortality outbreaks of Pacific oysters, Crassostrea gigas, in France in 2008. Virus Res 153:92-99

Sheehan D, Power A (1999) Effects of seasonality on xenobiotic and antioxidant defence mechanisms of bivalve molluscs. Comp Biochem Physiol C Pharmacol Toxicol Endocrinol 123:193-199

Sim-Smith C, Faire S, Lees A (2016) Managing biosecurity risk for business benefit: aquaculture biosecurity practices research. Tech Pap No. 2016/14. Prepared for Ministry for Primary Industries, Wellington

Sinner J, Forrest B, Newton M, Hopkins G, Inglis G, Woods C, Morrisey D (2013) Managing the domestic spread of harmful marine organisms. Part B: statutory framework and analysis of options. Prepared for Ministry for Primary Industries. Cawthron Rep No. 2442. https://www. cawthron.org.nz/publications/science-reports/

Steele CM, Brown RN, Botzler RG (2005) Prevalences of zoonotic bacteria among seabirds in rehabilitation centers along the Pacific coast of California and Washington, USA. J Wildl Dis 41:735-744

Stephens PR, Altizer S, Smith KF, Aguirre AA and others

Editorial responsibility: Brett Dumbauld,

Newport, Oregon, USA
(2016) The macroecology of infectious diseases: a new perspective on global scale-drivers of pathogen distributions and impacts. Ecol Lett 19:1159-1171

* Subasinghe RP (2005) Epidemiological approach to aquatic animal health management: opportunities and challenges for developing countries to increase aquatic production through aquaculture. Prev Vet Med 67:117-124

*Tan CKF, Nowak BF, Hodson SL (2002) Biofouling as a reservoir of Neoparamoeba pemaquidensis (Page, 1970), the causative agent of amoebic gill disease in Atlantic salmon. Aquaculture 210:49-58

* Taylor MD, MacKenzie LM, Dodgshun TJ, Hopkins GA, de Zwart EJ, Hunt CD (2007) Trans-Pacific shipboard trials on planktonic communities as indicators of open ocean ballast water exchange. Mar Ecol Prog Ser 350:41-54

Thieltges DW, Engelsma M, Wendling C, Wegner M (2013) Parasites in the Wadden Sea food web. J Sea Res 82: 122-133

Vakily JM (1989) The biology and culture of mussels of the genus Perna. ICLARM Contribution No. 494. International Center for Living Aquatic Resources Management, Manila

Vallat B (2017) The role of the OIE in aquatic animal diseases. www.oie.int/for-the-media/editorials/detail/article/therole-of-the-oie-in-aquatic-animal-diseases/ (accessed 9 Mar 2018)

*Villalba A, Mourelle SG, Carballal MJ, Lopez MC (1993) Effects of infection by the protistan parasite Marteilia refringens on the reproduction of cultured mussels Mytilus galloprovincialis in Galicia (NW Spain). Dis Aquat Org 17:205-213

*Wahl M, Schneider Covach S, Saderne V, Hiebenthal C, Muller JD, Pansch C, Sawall Y (2018) Macroalgae may mitigate ocean acidification effects on mussel calcification by increasing $\mathrm{pH}$ and its fluctuations. Limnol Oceanogr 63:3-21

Webb S (2013) Assessment of pathology threats to the New Zealand shellfish industry. Cawthron Rep No. 1334. https: //www.cawthron.org.nz/publications/science-reports/

* Webb SC, Castinel A, Duncan J (2019) New Zealand shellfish health monitoring 2007 to 2017: insights and projections. Cawthron Rep No. 2568. Prepared for the Ministry of Business, Innovation and Employment. https://www. cawthron.org.nz/publications/science-reports/

*Westfall KM, Gardner JPA (2010) Genetic diversity of Southern hemisphere blue mussels (Bivalvia: Mytilidae) and the identification of non-indigenous taxa. Biol J Linn Soc 101:898-909

Whittington RJ, Chong R (2007) Global trade in ornamental fish from an Australian perspective: the case for revised import risk analysis and management strategies. Prev Vet Med 81:92-116

*Whittington RJ, Paul-Pont I, Evans O, Hick P, Dhand NK (2018) Counting the dead to determine the source and transmission of the marine herpesvirus OsHV-1 in Crassostrea gigas. Vet Res 49:34

Submitted: October 29, 2018; Accepted: April 24, 2019 Proofs received from author(s): June 21, 2019 